\title{
Influence of Initial Carbon Concentration on Nitride Layers
}

Miroslav Pospíchal, Renata Dvořáková, Zbyněk Studený, Zdeněk Pokorný

Faculty of Military Technology, University of Defence, Kounicova 156/65, 66210 Brno, Czech Republic. E-mail: miroslav.pospichal@unob.cz, zdenek.pokorny@unob.cz

The properties of plasma nitride layer are determined except technological parameters by chemical compositon and structure of steel. Experiments were carried out on ARMOX 500T steel. Firstly, the samples of steel were carburized and isothermal hardened. After quenching the course of microhardness was measured from surface to the core of material. Samples were cutted off on metallographic saw and subsequently grinded from the surface to the core of material. All depths of grinded surface from surface to the core were exactly defined. The chemical composition was verified in each prepared samples. Samples with changeable content of carbon were nitrided by plasma nitriding technology. All properties of plasma nitriding layers were evaluated.

Keywords: Diffusion, Plasma nitriding, Armor steel

\section{Acknowledgement}

The paper was prepared with the support of the Project for the Development of the Organization and by the Specific research project 2014 of the Department of Mechanical Engineering, UoD "Promoting Research, Science and Inovation in the Field of Engineering".

\section{References}

[1] NIKOLUSSI, M., LEINWEBER, A., et al. (2007). Examination of phase transformations in the system Fe-N-C by means of nitrocarburising reactions and secondary annealing experiments, the $\alpha+\varepsilon$ two-phase equilibrium. In: Material Research, 98, 11, p. 1086-1092, ISSN 1862-5282.

[2] PYE, D. (2003). Practical nitriding and ferritic nitrocarburizing, USA, ISBN 0-87170-791-8.

[3] HOLEMÁŘ, A., HRUBÝ, V. (1989). Plazmová nitridace v praxi, SNTL, Prague, ISBN 80-03-00001-7.

[4] DATA SHEET, Armox 500T, SSAB Oxelösund, Version 2007-10-01,2p.

[5] DAVIS, J.R. (2002). Surface Hardening of Steel, ASM International Materials Park, ISBN: 0-87170-764-0.

[6] BHADESHIA, H.K.D.H. (2005). Hard Bainite. The Minerals, Metals and Materials Society, Cambridge CB2 3QZ, U.K., Volume 1, p. 469-484.

[7] PAYling, R., JONES, D., BENGTSON, A. (1997). Glow Discharge Optical Emission, Spektrometry. John Wiley \& Sons Ltd., England.

[8] POKORNÝ, Z., HRUBÝ, V., KUSMIČ, D. (2010). Plasma Nitridation of Bores in Barrels of Small-bore Rifles. Hutnické listy 2, vol. 63, s. 46-51. ISSN 0018-8069.

[9] STRÁNSKÝ, K. (1977). Termodynamika kvazistacionární difúze uhlíku v ocelích a její aplikace. Academia, Praha.

[10]SUKÁČ, J. (2013). Možnosti ovlivňování vlastností nitridovaných ocelí redistribucí intersticiálních prvků. Brno. Disertační práce. Univerzita Obrany, 77 s.

[11]HRUBÝ, V., MILLION, B., STRÁNSKÝ, K. (2001). Mikrotvrdost plazmově nitridovaných vrstev ocelí po implantaci a následném tepelném zpracování při teplotách 500-600 ${ }^{\circ} \mathrm{C}$. In: Kovové materiály, vol. 39, č. 2. S. 110 120. 